\title{
BEYOND CHILDREN'S BOOKS: GOVERNMENT PUBLICATIONS FOR CHILDREN AT THE RUTGERS UNIVERSITY LIBRARIES
}

\author{
BY \\ KAREN J. ZIMMERMAN
}

AND

B. J. SWARTZ

Karen Zimmerman is the Government Documents Assistant for the Rutgers-Camden Library.

B. J. Swartz is the Government Documents Librarian at the Rutgers-Camden Library.

\section{GOVERNMENT DOCUMENTS FOR CHILDREN AT RUTGERS}

It is likely that researchers using the Rutgers Libraries may not be aware of the existence of federal and state documents published for children. In some cases, these children's materials are unique sources. The folklore and legends found in the Indian Reading Series are nowhere so eloquently told. The history and meaning of American Indian arts are vividly described in Art and Indian Children of the Dakotas. The Constitution's Children provides a moving commentary from children on freedom in the United States. The lurking dangers of pollution are brought to light in There Lived a Wicked Dragon. The list is endless.

The importance of government documents for children can be briefly summarized. Government publications for children are often free or inexpensive, and a means for children to become informed citizens. These documents are also a reflection of a changing society. The time, effort, and expenditure necessary to disseminate such information, federally and statewide, exhibits the government's interest in the needs of those who are the adults of tomorrow. Therefore, it is most important for the population to be aware of these invaluable items. For an overview on how to go about obtaining federal documents for children, we encourage you to refer to the August 1989 issue of School Library Journal for "Hidden Treasure: Government Documents for Children \& Teens."

The following bibliography of federal and New Jersey documents for children provides a taste of the variety of such publications within Rutgers by subject area. Federal documents are listed with a "SuDoc" (Superintendent of Documents) number, which is the call number most often 
used. New Jersey documents are given a "DOCNJ" call number. The Rutgers libraries currently holding each title are indicated by the library name: ALEXANDER, CAMDEN, DANA, DOUGLASS, KILMER, LSM, Or SPECIAL COLLECTIONS.

\section{Alcohol and Drug Abuse}

Fat Albert $\mathcal{F}^{2}$ The Cosby Kids: Buzzy's Rebound (1986, SuDoc HE20.8302:B98) CAMDEN, DANA, LSM

For the child approaching the age where learning about alcohol abuse becomes of importance, this colorful comic book from the National Institute on Alcohol Abuse and Alcoholism provides excellent information. It focuses on Buzzy's alcohol problem when he substitute-coaches the basketball team. Fat Albert \& The Cosby Kids become aware of his problem and learn about the dangers of drinking and what alcohol can do to bodily functions.

Is Beer a Four Letter Word: An Alcohol Abuse Prevention Program Idea Book (1978, SuDoc

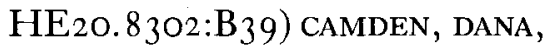
LSM

This colorful booklet, written for teens, is filled with activities designed to explain drinking, its cultural significance, and its dangers.

Rex Morgan, M.D. Talks ... About Your Unborn Child! (1980, SuDoc T70.2:C43) ALEXaNDER, CAMDEN, DANA

"Piense Primero En Su Hijo Que
Esta Por Nacer . ." Dice El Dr. Rex Morgan (i980, SuDoc T70.2: $\mathrm{C}_{43} / \mathrm{Spanish)}$ CAMDEN, DANA

These two comic books about alcohol are presented by the Bureau of Alcohol, Tobacco, and Firearms. Each story's message is conveyed through a realistic medical situation at the hospital where Rex Morgan and an associate explain the importance of prenatal care and the effects of alcohol on the mother and her baby to a pregnant woman and her husband.

This Side Up: Making Decisions About Drugs. (1980, SuDoc HE20.8202:T34/980) CAMDEN, DANA, LSM

The National Institute on Drug Abuse has provided a slick publication for kids in junior high and higher grades. Different types of drugs and their effects are described, followed by a fascinating history of drugs from the caveman to the present. A number of activities intended to boost self-respect and short readings on successful young people reinforce the value of being drug-free. The book is lively, interesting, and does not preach. 
ART

Art $\mathcal{E}$ Indian Children of the Da- into color. The heritage of the kotas: An Introduction to Art and Sioux is also told through the hisOther Ideas (1982, SuDoc tory of their art and through the I20.63:vol.) ALEXANDER (all legends that make up an eloquent vols.), DANA (vol. 2)

This magnificent set was developed for Sioux children by the Cultural Arts Curriculum Development Center, a field office of the Bureau of Indian Affairs. Besides being a five-volume series on the basics of art, the books go into detail on specific types of Indian art. The first four volumes are in black and white. The fifth volume leaps portion of the text. It is a moving commentary on how the old customs have disappeared as the Indians have been forced to accept more of the white man's ways. The series concludes with biographies of several Indian artists and samples of their work. It is regrettable that this valuable resource has gone out of print.

\section{CoIns}

How to Make a Penny at the Philaand other coins are made of, the delphia Mint (197I, SuDoc T28.2:P38/97 I) ALEXANDER, DANA

After describing what pennies steps in making a penny are illustrated. The story of the Philadelphia Mint follows.

\section{Crafts}

Toys: Fun in the Making (I979, SuDoc HE23. IOO2: T66) ALEXANDER, CAMDEN, DANA

This pamphlet, produced by the Administration for Children, Youth and Families, is filled with ideas for making toys and games from throwaway materials. Included are a list of materials for a "stuff box," recipes for paste, clay, and bubble solution, and safety tips and cautions.

\section{Culture}

Being Indian Is (Indian Reading Series, Level II, Book I9, c I 978 , SuDoc EDI.3 I9:2/I9) ALEXANDER, CAMDEN, DANA

With simplicity and eloquence, this booklet encourages pride in the
Indian heritage and traditions and in human dignity.

Far Out, A Rodeo Horse (Indian Reading Series, Level I, Book 9, c I977, SuDoc EDi.319:1/9) ALEXANDER, CAMDEN, DANA 
This story describes Far Out's life as a rodeo horse. He tells about his friends and about being ridden by a cowboy.

H'dE (1983, Sudoc EDi.2:H33) ALEXANDER, DANA

Produced by the Office of Bilingual Education of the Elementary Act of 1965 , this publication is written in English and Hualapai. It explains how the Hualapai Indians harvest and preserve the prickly pear tuni, H'đe. The fruit is used for its juice, as food, and to make jelly. Color photographs illustrate the description of the harvest and the preservation process. Some background information about the tribe is also supplied.

How Wild Horses Were Captured (Indian Reading Series, Level I, Book 2, cI977, SuDoc EDI.3 I9:I/2) ALEXANDER, CAMDEN, DANA

This fascinating booklet describes how horses were rounded up in the past and briefly tells how it is done today. Baseball fans might be interested in the function of the shortstop during the roundup.

Indian and Eskimo Children (1966, SuDoc I20.2:C43/5) ALEXANDER

Published by the Bureau of Indian Affairs, this collection of photographs, with text, tells about Indian and Eskimo children and their various ways of life. It is designed primarily to teach non-Indian chil- dren about the Indians and Fskimos.

Indian Festival (Indian Reading Series, Level I, Book 7, c I977, SuDoc EDI.3I9:I/7) ALEXANDER, CAMDEN, DANA

Indian culture is illustrated in this booklet. A boy named Joe describes an Indian festival with its traditional games, dances, parade, and rodeo.

KO (1983, SuDoc EDi.2:K79) ALEXANDER, DANA

This booklet comes from the Hualapai Bilingual Program in Arizona. The introduction tells about the Hualapai people. The text about the harvesting and use of Pinyon nuts, or Ko, is in Hualapai and English.

The Round Up (1986, SuDoc EDI.2:R76) ALEXANDER, CAMDEN

This short booklet describes the activities involved in a roundup - what the cowboys need, how they prepare, how they gather the cattle, how they drive them home or to the camp, how the cattle are cut out or separated, branded, ear marked, and castrated.

Stories of an Indian Boy (Indian Reading Series, Level V, Book I 8, c 98 I, SuDoc EDr.3 19:5/18) ALEXANDER, CAMDEN, DANA

Lance, an Indian boy, tells three stories about his long hair, his first fishing trip, and a day of clam digging. 
Tepee, Sun and Time (Indian Reading Series, Level II, Book I4, c I 978, SuDoc EDI.3 19:2/I4) ALEXANDER, CAMDEN, DANA

According to Indian custom, the entrance to the tepee was always situated to face the rising sun. The location of the morning sun on the poles corresponded to the seasons.

\section{ENERGY}

Energy Activities With Energy Ant (1975, SuDoc FEr.2:An8/3) ALEXANDER

The Energy Department provides an enjoyable way for children to learn about different types of energy through coloring, riddles, dot-to-dots, mazes, and other puzzles and activities.

\section{ENVIRONMENT}

Chessie: A Chesapeake Bay Story ( I 986, SuDoc I49.2:C42/4) CAMDEN, LSM (Figure I)

This United States Fish and Wildlife Service coloring book on environmental protection and wildlife preservation stresses the importance of Chesapeake Bay ecology to young children, with illustrations and a poem by the Loch Ness Monster's cousin, Chessie.

Earth Trek . . . Explore Your Environment (1977,

$\mathrm{SuDoc}$ EPI.2:Ea7/4) LSM

This environmental guide discusses the Earth as a closed system. Questions are posed and discussed on clean water, air, solid waste, noise pollution, and pesticides. Answers to the questions, checklists for action, and "What Would You Do?" activities are included.

The Processing and Recovery of Jon Thomas - Cool Cat! (I972, SuDoc EP I . 1 7:4ts) CAMDEN, LSM

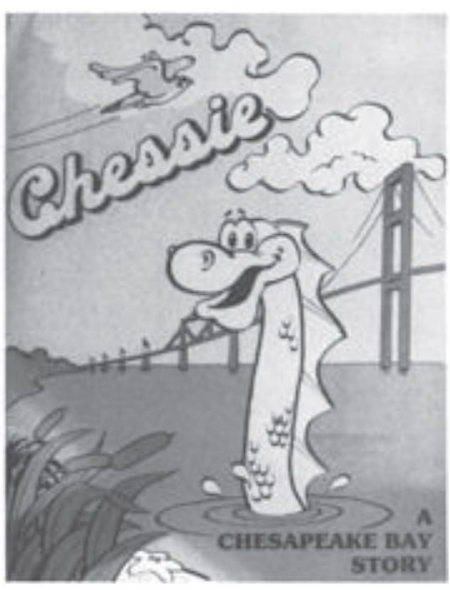

Figure I

Cover: Chessie:

A Chesapeake Bay Story

This Environmental Protection Agency coloring book explains the process of solid waste disposal and its importance. Jon Thomas is picked up with the trash and goes through the disposal process - almost becoming part of a sanitary landfill. 
Save Water. Every Drop Counts ( 1987 ?, DOCNJ TD224.N5 528 I) CAMDEN, DOUGLASS, KILMER, LSM

This activity book from the New Jersey Department of Environmental Protection is designed for children in kindergarten through sixth grade. Its purpose is to educate children about the importance of water conservation. Games, puzzles, pictures to color, and mazes attempt to make the learning experience fun!

Take Pride In America with Mark Trail: A Coloring Book (1987?, SuDoc I49.2:P93) CAMDEN, DANA, LSM (Figure 2).

Mark Trail takes some children on a trip through the different types of public lands and explains the lard's importance and vulnerability to such dangers as fire, pollution, and people.

There Lived a Wicked Dragon: an environmental coloring book for children and adults (1973, SuDoc EPI. I 7:I05) CAMDEN, LSM

This is a tale of a dragon who sleeps most of the time and feeds and grows on pollution. Occasionally a grown-up hears him and says something, but no one pays attention. Soon the dragon awakens and takes a bath in the river - which nearly ruins the river and every- thing that depends on it. The grown-ups realize what they have unleashed on the land, the air, and the water. They clean up the pollution and begin to dispose of solid waste properly When this is done, the dragon goes back to sleep. Water Story (Indian Reading Series, Level II, Book I 5, ci978, SuDoc ED I 3 I 9:2/I 5) ALEXANDER, CAMDEN, DANA

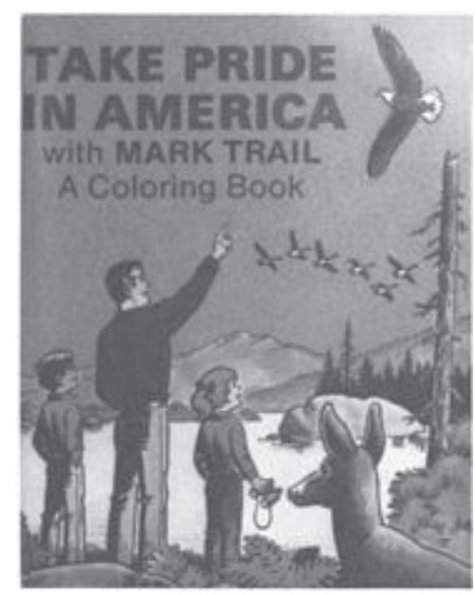

Figure 2

Cover: Take Pride in America with Mark Trail: A Coloring Book

The Crow Indians' respect for water is illustrated in this story, which tells the many aspects of water, how it changes through the seasons, and how it is important to life. It teaches a valuable lesson to adults as well as children. 


\section{FAMILIES}

Daddy's Days Away. A Deployment Activity Book For Parents \& Children (I987?, SuDoc D2 I 4.2:D12) ALEXANDER, CAMDEN

For the family with a father in the service, this offers important information and support. The booklet contains a list of resources for the mother, primarily focusing on childrearing. For the child's benefit, many of the activities are concerned with Dad's job, holidays, games, and drawings to color. A majority of the items instruct the child to think about the father while completing the activities. Others encourage the child to send the finished product to Dad, stressing the importance of keeping in touch with one another.

\section{FOLKLORE}

Birds and People (Indian Reading Series, Level I, Book I I, ci 977 , SuDoc EDi.3ig:I/II) ALEXANDER, CAMDEN, DANA

Beginning with a description of the flight and eating habits of various birds, this booklet cleverly continues to show that people do things differently and that no one way is the only one. The birds do not try to tell each other how to fly. Indian tribes are the same, each with different customs and languages. Different birds and different tribes "do things the way they know how."

Chipmunk Meets Old Witch (At-AtA'Tia) (Indian Reading Series, Level I, Book I2, c 1977, SuDoc EDI . 3 I 9: I/I 2) ALEXANDER, CAMDEN, DANA

One day Chipmunk wandered too far from home and was discovered by At-At-A'Tia, the old witch who ate children. She chased him up a tree, scratching his back as she grabbed for him. Chipmunk escaped her, but the marks on his back remain to this day.

Coyote And The Quail (1986, SuDoc ED I . 2:C83) ALEXANDER

While Coyote was sleeping, some quail took some of his butt fat and cooked it. When Coyote work up, he smelled something delicious and asked the quail if he could share some of their food. After he ate and was out of hearing, the quails chanted "Coyote ate his own butt fat and ran." Lizard told him what had happened. Meanwhile, the quails put some of their own feathers on a prickly pear. When Coyote came to ask who was making fun of him, they made him think it was the prickly pear. Coyote took a bite and got a mouthful of stickers.

Coyote and the Stars (Indian Reading Series, Level I, Book I, cI977, SuDoc EDI.3I9:I/I) ALEXANDER, CAMDEN, DANA 
Coyote goes up into the heavens to see the beautiful Indian girls. He joins their dance. His arms fall off and he falls to the earth, creating a great hole in the ground, which is red with dust from his blood.

Coyote Arranges the Seasons (Indian Reading Series, Level V, Book I 2, cI98 I, SuDoc EDi.3 I 9:5/I2) ALEXANDER, CAMDEN, DANA

Coyote thought he could do a better job than the sun. He tricked the sun, cut off his head, and took his place. He did not like the job, so he revived the sun and divided the year into four seasons. Winter was jealous of summer and killed summer's four brothers. The baby son of one of the brothers grew powerful and killed four of the five winter brothers. Each then ended up with power for half the year.

The Crow (Indian Reading Series, Level II, Book I3, c I978, SuDoc ED I . 3 I 9:2/I 3) ALEXANDER, CAMDEN, DANA

Crow was once colorful with a beautiful singing voice. He would not talk to anyone. Inkdomi, in the form of an eagle, tried to talk to him and was snubbed. Inkdomi turned the crow black and took away his beautiful voice.

How Birds Learned to Fly (Indian Reading Series, Level II, Book I6, c1 978, SuDoc ED I. 3 I 9:2/I6) ALEXANDER, CAMDEN, DANA

Crane bet that the other birds could not jump over him. Crow had been given the power to fly, and so succeeded.

How Horses First Came To The Gros VentrelRed Bird's Death (Indian Reading Series, Level V, Book I 7, c I 98 I , SuDoc ED I.3 I 9:5/I 7 ) ALEXANDER, CAMDEN, DANA

The first story is about a boy's quest for a red otter medicine bundle. Ultimately he is rewarded with the otter skin and a herd of horses. The second story continues his tale, as he returns to kill the red bird that took no pity on him in his quest.

How the Big Dipper and North Star Came To Be (Indian Reading Series, Level V, Book I4, c I98 I, SuDoc ED I . 3 I 9:5/I 4) ALEXANDER, CAMDEN, DANA

The youngest of seven brothers got a thorn in his hand. A little girl popped out and the brothers kept her and raised her as their daughter. She was captured by a monster who took her home to fatten her up and eat her. The creature's grandmother told the girl to kill her while the monster was away and cook her up. The girl escaped and she and her seven fathers flew up to the sky to become the Big Dipper and the North Star.

Insects Off To War (Indian Reading Series, Level I, Book 5, ci977, SuDoc EDI.3I9: I/5) ALEXANDER, CAMDEN, DANA

Grasshopper, Cricket, Ant, and 
Rainbug run out of things to talk about and decide to go to war to become famous and be called braves. All four are injured trying to cross the river and have to return home.

The Man Who Loved Shell Money (Indian Reading Series, Level III, Book I7, ci978, SuDoc ED I . 3 I 9:3/I 7) ALEXANDER, CAMDEN, DANA

This legend tells of a greedy man who loved only shell money. Duquakub, the great elk, told him where to find a great treasure. When he found it, he failed to give thanks to the Changer and found himself in a great storm. He was forced to cast away the strings of shell to please the evil forces, and was left with nothing. He slept for many years and returned to his village a wise and generous man.

Santa Claus Comes to the Reservation (Indian Reading Series, Level I, Book I4, ci977, SuDoc ED I.3 I 9:1/1 4) ALEXANDER, CAMDEN, DANA

This is a subtle and interesting story about differences in culture. Santa Claus used to get stuck in the tepee poles, but when the Indians moved to houses, he could park on the roof. Santa tried to be more like the Indians by shaving his beard and wearing braids and Indian clothing. The Indians suggested that he continue to wear his traditional costume in order to stay warm.
Tales of Coyote and Other Legends (Indian Reading Series, Level I, Book IO, ci977, SuDoc ED I.3 I 9: I/IO) ALEXANDER, CAMDEN, DANA

Five stories are presented here. "Peace" is about working together to find the Peace Spirit. "The Sucker and the Eel" tells why the sucker (fish) has more bones than the eel, who lost his gambling with the sucker. "Coyote, Deer, Obsidian and Rock: A Paiute Legend" is about how things came to be: obsidian is used for arrowheads to kill deer and the coyote is chased with rocks. "Fire and Frog" is a tale of why Indians make fire by rubbing dry willow sticks together. "Coyote and the Fishers" tells why we should not throw things away until they have been replaced.

White Rabbit (Indian Reading Series, Level V, Book I6, ci98I, SuDoc EDi.3 I9:5/I6) ALEXANDER, CAMDEN, DANA

This is the story of Mad Bear and White Horse Woman, who longed for a child, but Great Spirit had not given one to them. White Horse Woman found and took home a little white rabbit, which brought much joy to her and the village children. When White Rabbit got older, he left; and White Horse Woman dreamed of a beautiful little girl. Her dream came true with the birth of her child, who was named White Rabbit Woman. 
Why Bluejay Hops (Indian Reading Series, Level I, Book 6, ci977, SuDoc EDI.3 I 9:I/6) ALEXANDER, CAMDEN, DANA

Raven boasted of his skill in arrow shooting. Skatefish gave Raven three chances to hit him, but Raven missed three times. Bluejay challenged Raven next, thinking he could move as Skatefish did. $\mathrm{He}$ was hit with the second shot and hops from the injury to this day.
Winter Months (Indian Reading Series, Level V, Book I I, c I 98 I, SuDoc EDi.3 I9:5/II) ALEXANDER, CAMDEN, DANA

The leaders of the village were to vote on the number of cold months. All except Coyote agreed on three. With the help of Jumping Mouse, they tricked Coyote into not voting against them.

\section{FOOD AND Nutrition}

The 4 Food Groups For Better Meals Game (1974, SuDoc A98.9:122) CAMDEN

This rather unusual item was issued by the United States Department of Agriculture. Similar to Bingo, the game comes complete with instructions and 25 game cards. While playing the game, children will learn about the four food groups and have fun at the same time!

Fun with Good Foods (1 979, SuDoc A I .68: I 204) LSM

This coloring and activity book from the Food and Nutrition Service teaches about nutrition through coloring and other simple activities which are "arranged by order of difficulty," each activity building on the previous ones. It is intended for children ages four through eight, with the older children expected to need little assis- tance. Introductory material is provided for adults.

The Good Foods Coloring Book (1973, SuDoc A I.68:9 I 2/2) LSM

This coloring book, which is actually superseded by Fun with Good Foods, tells about foods from the four groups and what they do.

What's to Eat? And Other Questions Kids Ask about Food (1 979, SuDoc A I.IO:979) CAMDEN, DANA, DOUGLASS, LSM (Check with each library for location.)

The 1979 Yearbook of Agriculture answers these questions. With colorful writing and illustrations, games, quizzes, and other activities, just about every imaginable aspect of food and nutrition is covered. Also included are keys for Morse code, Semaphore, and the manual alphabet, with messages in each. 


\section{Health}

Chew Or Snuff Is Real Bad Stuff (I 988?, SuDoc HE20.3 I 58:Sm7/

7) CAMDEN, DANA, LSM

This pamphlet was published by the National Cancer Institute with the American Academy of Otolaryngology-Head and Neck Surgery, Inc. Although it is more useful in a classroom atmosphere, the last page of the guide contains a list of other resources available on the subject. A poster, pamphlets, and a videotape are listed along with how to go about obtaining them.

Get Fit: A Handbook for Youth Ages 6-I7 (I987, SuDoc HE20. I08: Y 8/2) DANA, LSM

The importance of physical fitness, what it is, and how it is measured are explained in this booklet from the President's Council on Physical Fitness and Sports. Qualifying scores for the Presidential Physical Fitness Award are given, followed by warmup and vigorous exercises. A fitness quiz concludes the handbook.

Hospital Days, Treatment Ways: Hematology-Oncology Coloring Book (1988, SuDoc HE20.3 152:H79/

\section{3) CAMDEN, DANA, LSM}

The National Cancer Institute produced this coloring book for the child being admitted to the hospital. It takes the child on a journey through a hospital visit. It is designed with the intent to educate both the parent and the youngster.
Each illustration is described by a simple, informative caption. The first two pages of the book consist of a more comprehensive explanation of the events illustrated on each page. By reading this preliminary section, the parent is prepared to answer any questions the child may raise about what is occurring in each drawing throughout the book.

Hospital Jobs: Things People Do in the Hospital, An Activity Coloring Book for Patients (1986, SuDoc HE2O.3OO2:H79/2) DANA, LSM

For each job in a hospital, this booklet provides the child with a picture to color, a description of the job, and space to write about his or her experience with that person.

Why Nick the Cigarette is Nobody's Friend (1966, SuDoc FSI4. I I : 447) CAMDEN

This Children's Bureau publication portrays Nick as a sleazy character who tries to trick kids into thinking that smoking is glamorous. Aimed at fourth and fifth graders, it tells why Nick is no good for sports, why he is a "gyp," and that he is addictive, poisonous, and a killer. Only the section on costs of smoking is outdated $\$$ I.00 certainly cannot buy movie tickets nowadays! This is an excellent method for showing the cigarette as being evil or as the "bad guy." 


\section{HistoRY AND GEOGRAPHY}

Constitutional Bicentennial Coloring Book (1987, SuDoc Dior. 2:C76/

2) ALEXANDER, DANA

As part of the Bicentennial of the United States Constitution, the Army published this coloring book. Following the pictures to be colored, many with a military theme, is a reprint of an Army pamphlet, This We'll Defend, about the Constitution, its history, and its relationship to the military.

The Constitution's Children: A Collection of Essays by Schoolchildren to Commemorate the Bicentennial of the U.S. Constitution I787-1987 (1987, SuDoc EDi.2:C76) ALEXANDER, CAMDEN, DANA

This was one of the highlights of the Bicentennial of the United States Constitution. The I 50 essays

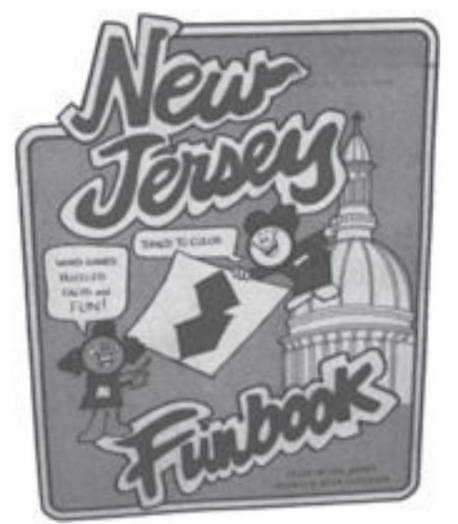

Figure 3

Cover: New Jersey Funbook by children in grades one through eight were selected from those submitted as part of a Department of Education project on "What the Constitution Means To $\mathrm{Me}$ and Our Country."

A Musical Skit for Children on the Constitution Convention (1987, SuDoc Y3.B47/2:2M97) ALEXANDER, CAMDEN, DANA

Another delightful publication about the Constitution presents a scene from "We All Are A Part Of It: U.S.A. I 776- I 840," written by Jean Lutterman, a music teacher from Bethesda, Maryland. The music and dialogue show the arguments between the Federalists and Anti-Federalists during the Constitutional Convention. Following the scene, questions for discussion, with further information, are given.

New Jersey Funbook (1985?, DOCNJ Fi34.3.V36 I985) ALEXANDER, CAMDEN, DOUGLASS (Figure 3)

This activity book, issued by the New Jersey Department of Human Services, is filled with games, puzzles, and drawings that teach children about the state of New Jersey. For example, children solve a maze to help George Washington cross the Delaware River. The solutions appear at the end of the document. 


\section{National Parks}

Children's Experimental Workshop. Expanding the Park Experience to Children with Special Needs (1978, SuDoc I 29. 2: C43/3) ALEXANDER, CAMDEN, DANA

Geared towards an adult interested in developing a similar project, the first portion of this $\mathrm{Na}$ tional Park Service document concentrates on the project's history. A child could benefit from this publication in numerous ways. It could be used in a classroom or home atmosphere, with an adult giving explanations about the pho- tographs of the handicapped children and the events portrayed.

The second portion of the text covers the art projects "developed for the Multicultural Arts Day Camp and for the workshop with handicapped children." In this section, step by step illustrations show how each project is undertaken. This provides a learning experience for many children by allowing them to read and visually follow the instructions. This document requires parental or adult guidance.

\section{Natural History}

The Corps Ranger's Handbook for Junior Campers: Doodle and Coloring Book (1988?, SuDoc Dio3.6/ $5: \mathrm{C}_{\text {I }}$ /2) LSM

The U.S. Army Corps of Engineers, Louisville District, has provided a brief handbook with activities on dams, trees, fire safety, wildlife (particularly birds and snakes), and water safety.

Discovering Delaware Water Gap: A Field Book for Young Naturalists (1978, SuDoc I29.2:D37/2) ALEXANDER, CAMDEN, DANA

With this United States Fish and Wildlife Service field guide, children learn about the history, geology, wildlife, and ecology of the Delaware Water Gap and its surrounding areas of New Jersey and Pennsylvania. The pamphlet in- cludes excellent illustrations, pages scattered throughout for notes, and several "Explorations" or activities.

How To Know the Wildflowers Near Your Camp (1981?, SuDoc A I $3 \cdot 36 / 2:$ W64/4) LSM

This field guide shows flower shapes and types of leaves, arranged by plant families, then individual wildflowers.

The Lives of Geese: Brant, Emperor, White-Fronted, and Cackling Canada Geese (1988, SuDoc I49. $2:$ G27/2) CAMDEN, DANA

This booklet begins with a discussion of geese in general, then continues with more detailed descriptions of the Brant, Emperor, White-Fronted, and Cackling Canada Geese. Fact boxes are scat- 
tered throughout the text. Informative maps, charts, statistics, and illustrations provide useful supplementary information to support the need for preservation of Alaskan waterfowl.

New Jersey Outdoors (bimonthly, DOCNJ SKI.N452) CAMDEN, DANA, DOUGLASS, KILMER, LSM, SPECIAL COLLECTIONS (Check with each library for location.)

Several issues of New Jersey Outdoors include Explorer, a special section for children. Topics have included articles and activities on agriculture, the environment, radon, ozone, birds, bears, the ocean, solid waste disposal, and Washington's crossing of the Delaware River.

Tengmiat Kiiki Amllerikilit (May the geese increase as soon as possible) (I 989 , SuDoc I49.2:G27) CAMDEN, DANA

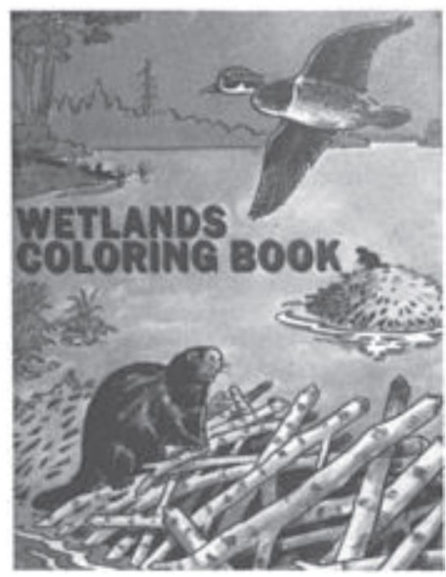

Figure 4

Cover: Wetlands Coloring Book
This item is difficult to categorize. Sent to federal depository libraries as a "general publication" of the United States Fish and Wildlife Service, it is a 1989 calendar produced jointly by the Alaska Department of Fish and Game, the National Audubon Society, and the Yukon Delta National Wildlife Refuge. The cover and each month are illustrated with pictures by the "Children of the Yukon-Kuskokwim Delta." Beneath each picture is a paragraph about the geese. The calendar itself includes a native name for each month, with its meaning, and native names for the days of the week. Besides the common holidays, dates are marked with drawings of various geese and facts about them. This unique mixture of art, culture, and nature makes for a fascinating document.

Wetlands Coloring Book (I986?, SuDoc I49.2:W53/IO) CAMDEN, DANA (Figure 4)

Jack Elrod, of "Mark Trail" fame, illustrated this coloring book which explores the environment and the natural habitat of various animals. Detailed illustrations of the animals are supplemented by labels and informative captions.

Your Aquarium - A Reflection of Nature (I 989?, SuDoc I49.2:Aq3/

2) CAMDEN, DANA

Nature is mirrored in miniature by the aquarium. The importance 
of oxygen, acidity, filtration, temperature, the day/night cycle, and size of the environment is illus- trated for both the aquarium and the natural habitat of aquatic life.

\section{OCCUPATIONS}

Choosing a Health Career, Featuring Wee Pals - The Kid Power Gang (1979, SuDoc HE20.6002:Ci $8 /$ 5) DANA, LSM

This outstanding comic book, prepared for the Health Resources Administration by United Feature Syndicate, Inc., teaches about career opportunities available in the health sciences. Scattered among stories and descriptions of various health careers are several biographical sketches of men and women in the health professions.

Historic New Jersey Occupations: A rich resource for the Career Aware- ness of today's children $\mathcal{E}$ youth ( 1975 , DOCNJ T22.N4Y6) CAMDEN, SPECIAL COLLECTIONS

This teacher's guide to career awareness activities focuses on historic site visitations and traditional crafts. Colonial recipes and how to make a corn husk doll are still current features of a fourteen-year-old publication. Some of the information is dated; yet for the individual with a true interest in these areas, this document will provide a phone number and an address in which to begin a search for more recent information.

\section{Postal Service}

And Now. . . The World's Greatest Hobby ... Getting Started in Stamp Collecting (With Basic Collecting Tools) (I983, SuDoc Pr.2:St2/15) ALEXANDER, DANA

Fortunately this brief document is not as long as its title! This United States Postal Service publication explains all of the basics involved in the hobby. Even an adult can learn something from this document. Both colorful and informative, the text ranges from the elements of a stamp (country, cancellations, etc.), how to obtain stamps, tools, to some "amazing philatelic facts."
A Coloring Book Story About Laura's Letter To Grandmother (1984, SuDoc Pi. 2:C7 I) ALEXANDER

This coloring book, one of many issued by the U.S. Postal Service, illustrates the journey of a letter from the sender to the recipient. Short captions explain each event. The last few pages contain drawings of stamps, just waiting to be colored.

You Are A Parcel, A package-eye tour of a Postal Service Bulk Mail Center (I983, SuDoc PI.2:P2 I/ I 5/983) ALEXANDER, DANA

In this short pamphlet, issued by the United States Postal Service, 
the child is instructed to pretend he or she is actually a parcel. The route of the parcel, containing roller skates, is traced from the manufacturer sending the skates to the retailer receiving them.

\section{SAFETY}

The Crime Prevention Coloring Book (ci 979, SuDoc D io i. 2:C86/

4) ALEXANDER, CAMDEN, DANA

McGruff, the familiar crime prevention dog, was borrowed by the Defense Department to pass on his crime prevention tips in this coloring book.

For Kids' Sake ... Think Toy Safety Coloring Book (n.d., SuDoc

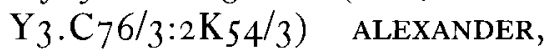
DANA

Some adults might do well to use this coloring book, which covers shopping for toys, putting things away, reading directions, age appropriate toys, fixing broken toys, flying toys, noisy toys, electric toys, and secure parts. Pages are included for children to draw their versions of both a safe and an unsafe toy.

It Hurts When They Cry: "Bumps" Activity Book (I986?, SuDoc

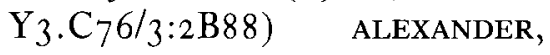
DANA

A sad infant, "Bumps," with an injured arm, is the central character in this booklet, which introduces safety lessons about baby carriers, playpens, strollers, walkers, and high chairs. Activities include coloring, dot-to-dots, choosing the safest item, word games, and a skit.
Little Leon the Lizard - Toy Safety Curriculum (1 976?, SuDoc Y $3 . C_{7} 6$ I 3:2L72) ALEXANDER, DANA

Leon the Lizard and other inhabitants of Safe Valley have several aventures teaching general toy safety, specifically about roller skates, running with toys, bow and arrow sets, wagons, and playing in trunks.

Look Out! It Burns! (1969, SuDoc FS I 7.2 I O:470) CAMDEN, DANA

This Children's Bureau publication is designed to teach a child about the dangers of fire and how to prevent it. Only twelve pages in length, it covers topics such as what allows a fire to burn once it has started, how it is dangerous, the elements of an escape plan, how to fight a fire, and how to prevent one in the first place. It contains interesting, basic information, even for use by an adult.

Otto Otter for Safe Water ( I 986?, SuDoc I 27.2:Ot8) DANA, LSM

Otto Otter helps the United States Bureau of Reclamation teach about water safety. After working through this coloring book, children should know about being safe in and around the water.

Play Happy, Play Safely: Little Big Kids for Ages 3-5 (1977?, SuDoc 
$\left.\mathrm{Y}_{3} \cdot \mathrm{C}_{7} 6 / 3: 8 \mathrm{~K}_{54} / 2\right)$ ALEXANDER, CAMDEN

Play Happy, Play Safely: Medium Big Kids for Ages 6-9 (1977?, SuDoc $\mathrm{Y}_{3} \cdot \mathrm{C}_{7} 6 / 3: 8 \mathrm{~K}_{54}$ ) ALEXANDER, CAMDEN

Play Happy, Play Safely: Big Big Kids for Ages I O-I 2 ( I 977 ?, SuDoc $\left.\mathrm{Y}_{3} \cdot \mathrm{C}_{76} 6 / 3: 8 \mathrm{~K}_{54} / 3\right)$ ALEXANDER, CAMDEN

Big kids from ages 3 to I 2 are taught playground safety in a series of three books from the Consumer Product Safety Commission. SayHey the frog appears in each book containing poems and stories written by children, followed by a "parents corner" with information on the importance of play and on playground safety.

Sprocket Man (1978, SuDòc

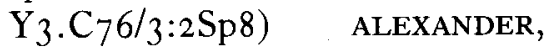
DANA

Sprocket Man, the super hero in this comic book from the Consumer Product Safety Commission, teaches bicycle safety, including traffic rules, equipment, and theft. A bibliography and a bicycle inspection checklist are included.

the super sitter (1987, SuDoc

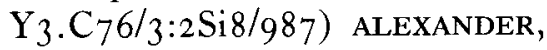
DANA

Important information on babysitting is presented in this pam-

phlet. The sitter learns what is expected of him or her and some information about the child's environment, including equipment and toys. A super sitter's surprise box for providing activities is suggested. Safety tips are given for outdoor play, pool safety, and poison prevention.

A Walk With Mommy: A Book on Safe Walking Skills (1985, SuDoc TD 8.2: $\mathrm{W}_{\mathrm{I}} 5 / 2 /$ Story 3) DANA, LSM

Traffic safety is taught to children of ages $2 \mathrm{I} / 2$ to 3 in this booklet from the National Highway Traffic Safety Administration. Important safety words, such as STOP or LOOK, are repeated three times for reinforcement.

Winter Survival Coloring Book (I 982, FEMI.2:W73/2) ALEXANDER

Cold weather safety is stressed in this document published jointly by the Federal Emergency Management Agency and the National Oceanic and Atmospheric Administration. The topics covered are dressing for the cold, fireplaces, electrical cords, space heaters, matches and candles, flashlights, weather reports, and smoke detectors.

\section{Space Science}

aer- $0^{-\cdot}$ nau- ${ }^{-}$tics (1988, SuDoc NASi.2:Ae8/I I) CAMDEN, DANA

For the curious child, this pro- vides answers about the science of flying. Seven simple illustrations add clarity to the informative text. 
Discovery Tour: Children Grades Pre-School through 3 (n.d., SuDoc SI9.2:T64) ALEXANDER, CAMDEN

This pamphlet is designed to prepare younger children for a visit to the National Air and Space Museum. Activity cards are included, as well as a bibliography for teachers, a bibliography for students, and a guide to aerospace resource materials.

Human Spaceflight (1985, SuDoc NASI. $2: \mathrm{H} 88 / 2$, NASI . $2: \mathrm{H} 88 / 3$, and NASI.2:H88/4) CAMDEN, DANA, LSM

Issued three times with three different cover titles (Activities for the Intermediate and Junior High Student, Activities for the Primary Stu- dent, and Activities for the Intermediate Student) this NASA document covers the history of spaceflight, life support, food, clothing, and waste management. Several activities, puzzles, quizzes, and worksheets are included.

Lunar Science: Activities for the Elementary Student (1983, SuDoc NAS I.2:L97) CAMDEN, DANA, LSM

Filled with puzzles, games, quizzes, and labelled drawings of a space suit and the Apollo spacecraft, this document offers plenty of information. Although no text appears, the exercises are learning experiences in themselves.

\section{Transportation}

NJ Transit Ride Guide Funbook (i 986?, DOCNJ HEI52.S25) DOUGLASS, LSM

This activity book teaches about the NJ Transit public transportation system. Filled with games, puzzles, and illustrations to color, the booklet explains how to find out which bus or train to take and how to be a safe passenger. This title is also available in Spanish (DOCNJ HE1 $52 . \mathrm{S}_{2} 5$ I 8 at LSM).

\section{WEATHER}

Hurricane Warning: A Booklet for Boys and Girls (1977?, SuDoc $\mathrm{C}_{55}$. 102:H94/7) DANA, LSM

Featuring Owlie Skywarn, this tells about Sue Ellen's experience during Camille. A wind scale chart explains what can happen at various wind speeds. It tells how a hurricane forms, what it does, how it is forecast, how to prepare, and what to do in case one strikes. There is also an exercise in tracking hurricanes.

A Look at Weather: Activities for Primary Students (1988, SuDoc NAS I. 2:W37/2) CAMDEN, DANA, LSM

This classroom activity guide for grades two to twelve includes weather lore and information on 
clouds, wind, tornadoes, thunder flash floods, what they are, the difstorms, lightning, and snow. Spe- ference between a watch and a cial topics are weather forecasting warning, and what to do in the (including surface analysis and satellite analysis), people who study weather (meteorologists), and phenology (the relationship between climate and periodic biological phenomena). Also discussed are weather radio stations, weather on Mars, and weather extremes.

Owlie Skywarn on Flash Floods (I98I, SuDoc C55.102:Sk9/3/ 98 I) DANA, LSM

The National Weather Service's Owlie Skywarn teaches what causes event of a flood.

Watch Out ... Storms Ahead! Owlie Skywarn's Weather Book (1983, SuDoc C55.102:Skg/4/ 983) DANA, LSM

These four pages from the $\mathrm{Na}$ tional Weather Service are packed with information on hurricanes, tornadoes, lightning, flash floods, and winter storms. Facts, safety tips, and quizzes teach children what to do in case of severe weather. 